\title{
Reexamining the Empirical Relation between Loan Risk and Collateral: The Roles of Collateral Liquidity and Types*
}

\author{
Allen N. Berger \\ University of South Carolina \\ Wharton Financial Institutions Center \\ European Banking Center \\ aberger@moore.sc.edu \\ W. Scott Frame \\ Federal Reserve Bank of Atlanta \\ scott.frame@atl.frb.org \\ Vasso Ioannidou \\ Lancaster University \& CEPR \\ v.ioannidou@lancaster.ac.uk
}

October 2015

\begin{abstract}
$\underline{\text { Abstract }}$
This paper offers a possible explanation for the conflicting results in the literature concerning the empirical relation between collateral and loan risk. We posit that differences in collateral characteristics, such as liquidity, may be associated with the empirical dominance of different risk-collateral relations implied by economic theory. Using credit registry data and a novel identification strategy to control for borrower and lender selection effects allows us to differentiate between the ex ante and ex post theories of collateral. We find that collateral overall is associated with lower risk premiums and higher default rates. The results indicate an important role for collateral in mitigating losses and reducing risk-taking incentives, consistent with ex post theories. Liquid collateral is associated with especially low risk premiums, and these loans perform better than those with illiquid collateral or no collateral. We also find that individual collateral types exhibit significant variation in terms of risk-collateral relations, with some consistent with ex ante theories and others with ex post theories. Our results suggest that the conflicting results in the literature may occur because different samples may be dominated by different types of collateral with different economic characteristics.
\end{abstract}

JEL Classification Numbers: G21, D82, G38

Keywords: Collateral, Asymmetric Information, Banks

* The views expressed do not necessarily reflect those of the Federal Reserve Bank of Atlanta or the Federal Reserve System. The authors thank the editor, Charles Calomiris, the anonymous referee, as well as Sumit Agarwal, Rob Bliss, Fabio Castiglionesi, Peter Cziraki, Hans Degryse, Joost Driessen, Giacomo Nocera, Steven Ongena, Raluca Roman, Dave Solomon, and participants at the Chicago Federal Reserve's Bank Structure and Competition Conference, Financial Intermediation Research Society Conference, International Banking, Economics, and Finance Association Meetings, Financial Management Association Meetings, and seminars at Tilburg University and University of North Carolina at Charlotte for helpful comments. 


\section{Introduction}

Collateral is a prominent feature of debt contracts, and significant declines in the value of widely pledged assets can amplify the business cycle through procyclical changes in credit availability, including during the recent financial crisis (e.g., Bernanke and Gertler, 1989, 1990; Kiyatoki and Moore, 1997; Gan, 2007; Boz and Mendoza, 2014; Gorton and Ordonez 2014). As U.S. housing prices began falling in the latter half of the 2000s, mortgage defaults rose substantially and the value of mortgage-related collateral plummeted. As a result, households' ability to borrow against their homes and financial institutions' ability to pledge or sell mortgage-backed securities became impaired.

While these events suggest that secured credit may be associated with higher risk, economic theory suggests that collateral pledges may be associated with either higher or lower risk. The presence of collateral is generally explained as an attempt to reduce agency costs or contracting frictions in the presence of asymmetric information. ${ }^{1}$ One strand of theory focuses on ex ante private information and suggests that collateral may allow lenders to sort observationally equivalent loan applicants through signaling. ${ }^{2}$ Specifically, lenders offer a menu of contract terms such that observationally equivalent applicants with higher-quality projects choose secured debt with lower risk premiums, while those with lower-quality projects elect unsecured debt with higher risk premiums. A second set of theories motivates collateral as part of an optimal debt contract by invoking ex post frictions, like moral hazard, and predicts that observably riskier borrowers are more likely to be required by lenders to pledge collateral. ${ }^{3}$

\footnotetext{
${ }^{1}$ Some theories of collateral do not emphasize the roles of asymmetric information. For example, Inderst and Mueller (2007) show that collateral may be required by local relationship lenders facing competition from distant transactional lenders to boost profitability when lending to risky borrowers. In addition, Manove, Padilla, and Pagano (2001) emphasize the role of collateral as a substitute for bank screening of borrowers.

${ }^{2}$ For examples of these theoretical models, see Bester (1985, 1987), Besanko and Thakor (1987a, 1987b), Chan and Thakor (1987), and Boot, Thakor, and Udell (1991).

${ }^{3}$ See Boot, Thakor, and Udell (1991), Boot and Thakor (1994), Aghion and Bolton (1997), and Holmstrom and Tirole (1997) for examples of models with moral hazard. Other ex post frictions modeled in the literature include difficulties in enforcing contracts (e.g., Banerjee and Newman, 1993; Albuquerque and Hopenhayn, 2004; Cooley, Marimon, and Quadrini, 2004) and costly state verification (e.g., Townsend, 1979; Gale and Hellwig, 1985; Williamson, 1986; Boyd and Smith, 1994).
} 
To test these theories, a number of empirical studies link measures of loan risk - such as loan risk premiums (loan rates minus the risk-free rate) and ex post nonperformance (delinquency or default) - to whether or not collateral was pledged. The findings presented in these papers are mixed. Some studies report a positive relation between loan risk premiums and collateral (e.g., Berger and Udell, 1990; Blackwell and Winters, 1997; Machauer and Weber, 1998; John, Lynch, and Puri, 2003; Brick and Palia, 2007; Godlewski and Weill 2011), while others find a negative relation (e.g., Degryse and Van Cayseele, 2000; Lehmann and Neuberger, 2001; Agarwal and Hauswald, 2010; Berger, Frame, and Ioannidou, 2011; Cerqueiro, Ongena, and Roszbach, forthcoming). ${ }^{4}$ One study finds no significant relation between collateral and loan risk premiums for loans drawn under commitment (Berger and Udell, 1995). In addition, two studies find that ex post nonperformance of loans is positively related to collateral (Jimenez and Saurina, 2004; Berger, Frame, and Ioannidou, 2011).

To our knowledge, there are no attempts to explain this puzzle in the literature - why the empirical relation between measures of loan risk and collateral is sometimes positive and at other times negative. This paper provides a potential solution by examining the empirical relation between loan risk and the economic characteristics and types of collateral. The implication is that the prior literature may have conflicting results because the secured loans in various data samples may be dominated by different types of collateral with different economic characteristics.

The degree to which information-based contracting frictions are mitigated by collateral should depend on the underlying economic characteristics of the collateral. All else equal, we hypothesize that the relation between collateral and loan risk should be stronger when the observable economic characteristics and types of collateral are more desirable to the borrower or lender. Under the ex ante signaling theories of collateral, the unobservably safest borrowers are expected to pledge the collateral

\footnotetext{
${ }^{4}$ Agarwal and Hauswald (2010) report a negative relation between commercial loan rates and the incidence of collateral. The result is presumably consistent with a negative relation between loan rate premiums and collateral, given that risk-free rates changed only modestly during their 15 -month sample period. Using a differences-indifferences approach, Cerqueiro, Ongena, and Roszbach (forthcoming) find that following the change in the law and the loss in collateral value borrowers pay a higher interest rate on their loans, receive a worse quality assessment by their bank, and experience a substantial reduction in the supply of credit by their bank.
} 
that is most desirable to them. Under the collateral theories featuring ex post contracting frictions, the lender is likely to insist on collateral from the riskiest borrowers that is most desirable to the lender or the borrower. In our analysis below, we focus on whether collateral can be characterized as being liquid or illiquid - with liquid collateral being more desirable - as well as on different types of collateral that may be more or less desirable.

Some prior research analyzes individual economic characteristics of collateral and collateral types. Berger and Udell (1995) find that neither accounts receivable and inventory nor other types of collateral have significant effects on loan rate premiums on lines of credit for a sample of U.S. small businesses. John, Lynch, and Puri (2003) study U.S. corporate debt and find that non-mortgage collateral pledges are associated with higher interest rates than mortgage collateral pledges and unsecured loans - a result that is stronger for longer-term loans and loans to riskier firms. Voordeckers and Steijvers (2006) examine small commercial loans from a large Belgian bank and find that the pledging of outside collateral (assets not otherwise legally attachable in the event of default) is more likely for informationally opaque firms (i.e., loans made to younger and family firms and firms with small loans). Brick and Palia (2007) find that higher interest rates are charged for small business loans backed by outside collateral relative to inside collateral. Benmelech, Garmaise, and Moskowitz (2005) find that the terms of commercial real estate loans are affected by the zoning regulations associated with the underlying properties, which the authors use as a measure of redeployability. We consider "redeployability" to be an aspect of "liquidity" because it easier to dispose of the asset. The study finds that more redeployable assets receive larger loans with longer maturities and lower interest rates. Liberti and Sturgess (2014) find that banks are willing to accept firm-specific assets susceptible to agency risk (e.g., plant, machinery, and inventory) for low agency risk firms and prefer non-specific assets (e.g., real estate, cash and bank guarantees) for firms that are most prone to agency risk. Some non-specific assets, such as cash and bank guarantees, are consistent with our notion of collateral liquidity below.

Three other papers empirically demonstrate that airline financing conditions are related to the redeployability (liquidity) of the firm's fleet. First, Benmelech and Bergman (2008) find that airlines are 
better able to renegotiate their airplane leases when the liquidation value of their fleet is low. Second, Benmelech and Bergman (2009) find that the pricing of collateralized debt obligations financing airplanes depends on the aircraft model as bonds backed by more redeployable (liquid) airplanes carry lower interest rates. Finally, Benmelech and Bergman (2011) show that airline bankruptcies produce a negative externality for other firms in the industry by increasing the available supply of airplanes. The authors identify this "collateral channel" using prices for collateralized debt obligations - finding that the effect is stronger for less redeployable (liquid) models, less senior tranches, and higher loan-to-value ratios.

This paper significantly extends the empirical literature by studying the relations between two measures of loan risk (loan risk premiums and ex post nonperformance) and collateral overall, as well as with liquid versus illiquid collateral, and various collateral types using detailed commercial loan data provided by a national credit registry. We first examine collateral on the extensive margin - comparing the pledging of any type of collateral with no collateral, consistent with most of the extant literature. We then examine the intensive margin by considering differences between liquid and illiquid collateral, and types of collateral.

A positive relation between loan risk and collateral would suggest the empirical dominance of the ex post theories as higher loan risk premiums and ex post nonperformance indicate that riskier borrowers are being required by lenders to pledge collateral. However, negative coefficients would be ambiguous as they could indicate either: (1) empirical dominance of the lower inherent risks of the borrowers that signal their safety by choosing secured loan contracts under the ex ante theories; or (2) empirical dominance of the ex post theories where the loss-mitigating effects of collateral and/or the incentive effects to take less risk under these theories more than offset the higher inherent risks of the secured borrowers. Importantly, for our loan risk premium analysis, we are able to include firm-bank-time fixed effects that help us to better differentiate between the two main theories of collateral by eliminating the selection effects by both 
borrowers and lenders and leaving only the loss-mitigating effects and incentive effects to take less risk from collateral, which are more associated with the ex post theories. ${ }^{5}$

Our empirical analysis begins by relating our two measures of loan risk to a simple indicator of whether collateral was pledged to explore the extensive margin of collateral. We consistently find that collateral is associated with lower loan risk premiums, which may be consistent with either the ex ante or ex post theories. Our novel dataset allows us to use fixed effects to control for lender and borrower selection effects, which resolve the ambiguity and indicate that the data are consistent with the empirical dominance of the ex post theories. We also find that collateral is associated with a higher incidence of ex post nonperformance, reinforcing this conclusion.

We next explore whether liquid or illiquid collateral is more associated with loan risk using the subset of secured loans along the intensive margin. We find that liquid collateral is consistently associated with both lower loan risk premiums and ex post non-performance. This is also consistent with the ex post theories, as liquid collateral appears to have especially strong risk-reducing incentives. This finding is confirmed when we return to the full loan sample and study the differing relations among loan risk and liquid collateral, illiquid collateral, and no collateral. Here liquid collateral is again associated with both lower loan risk premiums and ex post non-performance; but illiquid collateral is associated with lower loan risk premiums and a higher incidence of ex post nonperformance. Nevertheless, for reasons discussed below, both findings are consistent with the empirical dominance of the ex post theories.

Finally, we analyze the relations between our two loan risk measures and nine different collateral types. The findings are mixed. While most collateral types appear to be consistent with the empirical dominance of the ex post theories, the results of some are more consistent with the ex ante theories.

Overall, we conclude that the conflicting findings in the literature may occur because different samples may be dominated by different types of collateral with different economic characteristics like

\footnotetext{
${ }^{5}$ Khwaja and Mian (2008) and Schnabl (2012) employ a similar identification strategy to control for unobservable firm characteristics. In their setting, these fixed effects are used to control for unobservable firm characteristics that may affect firms' demand for credit.
} 
liquidity. We suggest that whenever these characteristics can be identified or different collateral types are available, researchers should include them as their findings may be substantially enriched.

The remainder of the paper is structured as follows. Section II describes the credit registry data we use. Section III outlines our empirical tests and Section IV presents our main results. Section V concludes.

\section{Data}

Our commercial loan data come from the Central de Información de Riesgos Crediticios (CIRC), the public credit registry of Bolivia, provided by the Bolivian Superintendent of Banks and Financial Entities (SBEF). Prior research uses these data to address different research questions (e.g., Ioannidou and Ongena, 2010; Berger, Frame, and Ioannidou, 2011). Since CIRC's creation in 1989, the SBEF requires all formal (licensed and regulated) financial institutions operating in Bolivia to report detailed information on all loans. Our sample covers the credit registry for the period between January 1998 and December 2003. For each loan, we have information on origination and maturity dates, credit type, interest rate, collateral type, and ex post nonperformance (delinquencies and defaults) through the sample period. For each borrower, we have information about their industry, physical location, legal structure, banking relationships, and whether they have been delinquent or defaulted on another loan in the recent past.

The data include loans from both commercial banks and nonbank financial institutions (e.g., private financial funds, credit unions, mutual societies, and general deposit warehouses). To keep the set of lenders homogenous in terms of financial structure and regulation, we focus exclusively on loans granted by the 13 commercial banks operating in Bolivia between March 1999 and December 2003. ${ }^{6}$ Our

\footnotetext{
${ }^{6}$ Although we have data as of January 1998, we start our sample in March 1999 since prior to this date the data do not allow us to distinguish been commercial and consumer loans. However, we use the prior information from January 1998 through February 1999 to help fill in the history of bank-firm relationships as well as the firm's credit history as of March 1999.
} 
sample of firms draws mostly from the larger and less risky firms in Bolivia, as smaller and riskier firms can only access microcredit institutions. Even for our sample of relatively larger firms, there is very little reliable information other than what is available through the credit registry, as the vast majority of Bolivian firms do not have audited financial statements. Moreover, capital markets are not well developed and the banking sector is the principal source of debt finance for most of these firms (Sirtaine, Skamelos, and Frank 2004).

There are several types of commercial credit contracts in the data, including credit cards, overdrafts, installment loans, discount loans, and lines of credit. We focus exclusively on installment loans and discount loans, which together account for 92 percent of the total value of commercial loans during the sample period. Ninety eight percent of the installment and discount loans are denominated in U.S. dollars and we only use these loans in our analysis. To ensure the use of timely information, we only use new loans and exclude renegotiations ${ }^{7}$ and loans drawn on pre-existing lines of credit. $^{8} \mathrm{We}$ exclude loans with multiple types of collateral. The resulting sample encompasses 28,252 loans (to 2,462 different firms) of which 17.7 percent are secured.

The types of security interests that Bolivian banks can invoke when accepting collateral are determined by law. ${ }^{9}$ Acceptable security interests on real property include mortgages, pledges, and collateral bonds. Mortgages are used for immovable property (e.g., real estate) and some types of movable property (e.g., vehicles, aircraft, and boats). Pledges and collateral bonds, on the other hand, are security interests on other kinds of movable property (e.g., equipment, inventory, and accounts

\footnotetext{
${ }^{7}$ Banks are required to indicate whether a loan is a renegotiation of a previous (performing or nonperforming) loan and we use this information to exclude renegotiations. To the extent that some renegotiations are not recorded (either because of reporting errors or because banks do that intentionally to reduce their loan loss reserves), our sample will include some loans renegotiations as new loans. Hence, in the sensitivity analysis below we try to control for this possibility by dropping all "suspected renegotiations" from our sample.

${ }^{8}$ Loans drawn on pre-existing lines of credit are identified as follows. When a borrower draws on a pre-existing line of credit, a "new loan" appears in the registry with an origination date and contact terms as of the date the bank originated the credit line. Since the date the loan first appears in the registry is subsequent to the origination date, we can identify when a "new loan" is a draw on a pre-existing line of credit and then exclude it from our sample.

${ }^{9}$ Ley de Bancos y Entidades Financieras, Law No. 1488 of April 14, 1993.
} 
receivable). There are two classes of pledges: with and without transfer of possession. Pledges with transfer of possession (often referred to as "common pledges") require the transfer of movable property to the creditor or an authorized warehouse. Pledges without transfer of possession, on the other hand, are often used when the property is essential for the firm's operations. ${ }^{10}$ A collateral bond (also known as a warrant) is a security issued by an authorized warehouse indicating possession of an asset and its value. By endorsing the collateral bond to a lender, the firm pledges the deposited assets to obtain secured credit. Hence, collateral bonds are similar to pledges with transfer of possession. In addition to security interest on real property, Bolivian banks can also use security interest on financial assets such as bank guarantees, deposits in financial institutions, and financial securities.

All types of security interests used by Bolivian banks must be registered with the pertinent authorities, along with the encumbered assets. This is a time consuming and expensive process that often renders the use of collateral as impractical or prohibitively expensive, which may explain why the incidence of collateral in Bolivia is low relative to other countries. ${ }^{11}$ Registration allows for a more efficient enforcement in the event of default with the use of "Processo Coactivo Civil."12 The "Processo Coactivo Civil" is a faster enforcement procedure that escapes automatic stay and allows lenders to invoke their security interests once the borrower has materially bridged its contractual obligations. ${ }^{13}$

\footnotetext{
${ }^{10}$ When there are concerns about agency problems, a warehouse can be set up at the firm's premises to control access to the asset and at the same time allow the firm to continue using the asset.

${ }^{11}$ According to the World Bank (2005), registering property in Bolivia takes on average 91 days - well above the same figure for the Latin American and the Caribbean regions overall (56 days) or for OECD countries (34 days). Similarly, the average cost of creating collateral (as a percentage of gross national income per capita) is 51 percent for Bolivia as opposed to 19 percent for Latin America and the Caribbean and five percent for OECD countries.

${ }^{12}$ Ley de Abreviación Procesal y Asistencia Familiar, Law No. 1760 of February 28, 1997.

13 All other firm assets and obligations instead are subject to automatic stay once bankruptcy proceedings begin. Given the lengthy bankruptcy proceedings that characterize Bolivia and many other Civil Law countries, the recovery rates on such credits are often low (e.g., Djankov, McLiesh, and Shleifer (2008)).
} 
Table 1 provides variable names, definitions, and summary statistics for all loans in the sample. ${ }^{14}$ At the time of loan origination, only 0.3 percent of the loans are given to firms that have defaulted in the prior 12 months (Prior_Default). Hence, it seems that firms that default rarely get another loan — either because they are credit rationed or because they cease to exist as a going concern. About 21.1 percent of the loans are given to firms that had a delinquency with any bank in the previous 12 months (Prior_NPL). Many of the sample firms are limited liability corporations (48.8 percent), while joint stock corporations (22.2 percent), limited partnerships (13.6 percent), sole proprietorships (12.6 percent), and general partnerships ( 0.8 percent) are less common. The estimated average length of a banking relationship is almost 23 months. This is defined as the number of months since the first loan in the data for the bankborrower pair as of January 1998. Turning to loan characteristics, almost half of the sample consists of installment loans. The average loan amount is $\$ 148,902$, the average loan maturity is almost 11 months, and the average loan interest rate is 13.5 percent, with an average spread of 9.5 percentage points over U.S. Treasury securities of comparable maturities.

About 17.7 percent of our sample loans are secured by one of nine different types of assets. Of the collateralized loans, nine percent are secured by deposits in the same or another financial institution, almost four percent are secured by bank guarantees (such as letters of credit), and about two percent with securities (such as bonds and stocks). Movable firm assets (such as accounts receivable, inventory, crops, tools, machines and equipment) are frequently pledged. For our sample, almost 16 percent of collateralized loans are secured by creditor-held movable collateral and almost 25 percent are secured by debtor-held movable collateral (i.e., pledges with and without transfer of possession). Real estate is also a frequent form of collateral, as 20 percent of collateralized loans are secured by residential real estate and almost nine percent by commercial real estate. Finally, almost 14 percent of collateralized loans are secured with endorsements from deposit warehouses backed by the deposit of commodities (i.e., collateral

\footnotetext{
${ }^{14}$ For relationship length, loan amount, and maturity we report summary statistics for the level of these variables, but our empirical models (below) incorporate the natural logarithm of one plus the level.
} 
bonds), and two percent by vehicles. With respect to ex post performance of the 25,918 loans that matured before the end of the sample period, 5.9 percent had ex post delinquencies or defaults.

Different collateral types may be associated with certain economic characteristics. Our analysis principally distinguishes between liquid and illiquid collateral to illustrate the sensitivity of the empirical relation between loan risk and collateral characteristics. An asset is considered liquid if it can be converted into cash quickly without substantial discount on its price. Hence, we create an indicator variable, Liquid, that takes a value one when the collateral is Pledged Deposits, Bank Guarantees, or Securities. As shown in Table 1, about 15 percent of secured loans employ liquid collateral (with the remaining 85 percent of secured loans using illiquid collateral). All else equal, liquidity is considered to be a desirable economic characteristic for both borrowers and lenders.

The high degree of dollarization of the Bolivian credit market differentiates it from other countries in the region and around the world. In this case, banks may be additionally exposed to exchange rate risk if a loan is denominated in dollars and the collateral is non-tradable and salable only in the local currency (e.g., real estate). ${ }^{15}$ This may also affect the distinction between liquid and illiquid collateral, since more of the liquid collateral (such as pledged deposits) may be denominated in dollars, while more of the illiquid collateral may be denominated in local currency. This implies that in economies with high degree of dollarization, liquid collateral may be more attractive to banks because it may be less exposed to exchange rate risk (i.e., their future liquidation values maybe less susceptible to discounts from future depreciation of the local currency vis-à-vis the dollar). Nevertheless, this does not alter our main conclusions that differences in the distributions of collateral characteristics and types in the data sets employed by researchers may result in different risk-collateral relations. Rather it implies that these relations may also interact with country-specific factors affecting the relative attractiveness of different types of collateral.

\footnotetext{
${ }^{15}$ Honohan (2007, Table 1) presents some figures illustrating the degree of dollarization in various developing countries. High dollarization is not uncommon among developing countries who are experiencing (or did so in the past) hyperinflation.
} 
Table 2 presents the sample statistics for Risk_Premium and Ex_Post_Nonperformance. These are first delineated by whether the loan is secured or not; and then among secured loans whether the collateral is considered to be Liquid or Illiquid; and finally by collateral type. Collateralized loans have, on average, lower loan risk premiums and higher ex post nonperformance than uncollateralized loans. Among the subsample of collateralized loans, loans secured by liquid collateral on average maintain lower loan risk premiums and reduced ex post nonperformance relative to loans with illiquid collateral. Looking across collateral types, loans secured by Bank Guarantees or Creditor-Held Movable Assets carry the lowest average risk premiums and Residential Real Estate the highest. In terms of ex post nonperformance, loans backed by Pledged Deposits or Bank Guarantees performed the best on average. This is the first preliminary evidence that the risk-collateral relation may vary with collateral characteristics and types.

Table 3 presents a correlation matrix of the loan risk variables with the collateral variables. Collateral pledges overall are negatively correlated with loan risk premiums and positively correlated with ex post nonperformance, suggesting an ambiguous relationship between collateral and risk (to be reconciled in the regression analyses below). However, there are differences between liquid and illiquid collateral. Liquid Collateral is negatively correlated with both loan risk measures - a feature specifically driven by Pledged Deposits and Bank Guarantees. By contrast, Illiquid Collateral is negatively correlated with loan risk premiums and positively correlated with ex post nonperformance. This relation is consistent across the six illiquid collateral types in our data - except that loans secured by Residential Real Estate are associated with higher risk premiums. These correlations suggest that individual collateral characteristics and types may have different relations with the loan risk measures.

\section{Empirical Analysis}

We examine the relation between loan risk and collateral by conducting empirical tests using two different measures of loan risk - loan risk premiums and ex post nonperformance. We first examine collateral on the extensive margin - comparing the pledging of any type of collateral with no collateral, 
consistent with the extant literature. We later examine the intensive margin by considering the economic characteristics and types of collateral.

We run four loan risk premium regressions for the extensive margin using OLS, each including a different set of control variables. These regressions take the general form:

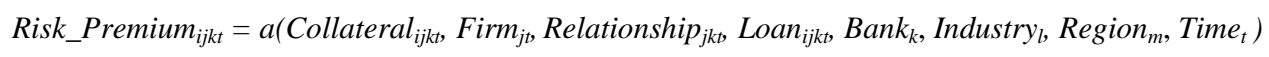

where $i, j, k, l, m$ and $t$ index loans, firms, banks, industries, regions, and time, respectively, and differ according to which of the controls are included. In these regressions, Risk_Premium is defined as the loan interest rate minus the rate on U.S. Treasury securities of comparable maturity for the month of loan origination. ${ }^{16}$ The key explanatory variable is a simple indicator of whether the loan was collateralized or not - Collateral .

In the first regression, we include only a few control variables. We include Installment, a dummy variable equal to one if the contract specifies an installment loan rather than a discount loan because these two types of loans have different repayment structures. We also include Region, a set of dummy variables that indicate the location from which the loan was originated. This includes nine regions in Bolivia as well as Argentina, Paraguay, Panama, and the United States. Moreover, bank and time (month-year) fixed effects are included in the model, represented by Bank and Time, respectively. Bank fixed effects are designed to capture systematic differences across banks in the pricing of their commercial loans. The time fixed effects are intended to account for temporal differences in loan risk premiums related to business, interest rate, seasonal, or credit cycles.

As discussed in the introduction, the coefficient on Collateral may help reveal whether the ex ante signaling theories that address the adverse selection problem or the ex post requirements to address the moral hazard problem are relatively more important. A positive coefficient would suggest empirical dominance of the ex post theories as a higher Risk_Premium would indicate that riskier borrowers are

\footnotetext{
${ }^{16}$ U.S. Treasury interest rates are interpolated to estimate rates for different maturities.
} 
being required by lenders to pledge collateral and are being charged a higher rate to compensate for this risk. However, a negative coefficient would be ambiguous. It could indicate the lower inherent risks of the borrowers that signal their risk by choosing secured loan contracts under the ex ante theories. Alternatively, it could reflect that the ex post theories were more prevalent, but that the loss-mitigating effects of collateral and/or the perceived incentive effects to take less risk more than offset the higher inherent risks of the secured borrowers. We show below a specification that disentangles these effects.

In the second specification of equation (1), we add firm characteristics for the past nonperformance of the firm, legal structure of the firm, industry, and relationship with the bank. Past nonperformance is measured by Prior_Default, which indicates whether the borrowing firm had defaulted on a loan with any lender in the previous 12 months and Prior_NPL, indicates whether the borrowing firm missed a payment on a loan with any lender in the previous 12 months. The set of dummy variables indicating the legal structure of the firm are General Partnership, Limited Partnership, Joint Stock Company, and Limited Liability Corporation (Sole Proprietorship is the omitted group). Industry is a set of 18 dummy variables controlling for the firm's industry classification (similar to the SIC and NAICS codes in the U.S.). ${ }^{17}$ Finally, we include Relationship Length, which indicates the length of a bank-firm relationship and it is equal to the natural logarithm of one plus the number of months we observe the bank and borrower in a credit relationship. This specification has almost the same interpretations of the coefficient on Collateral as the first specification, except that the selection effects by both borrowers and lenders are attenuated because there are more controls included for the borrower's risk.

Our third specification of equation (1) includes firm fixed effects interacted with bank and time fixed effects, i.e., Firm $_{j}{ }^{*}$ Bank $_{k} *$ Time $_{t}$ fixed effects. Time-invariant firm and industry variables and relationship length, as well as the individual bank and time fixed effects must be omitted from this

\footnotetext{
${ }^{17}$ The 19 industry categories are: Agriculture and cattle; Farming; Forestry and fishery; Extraction of oil and gas; Minerals; Manufacturing; Electricity, gas, and water; Construction; Wholesale and retail trade; Hotels and restaurants; Transport, storage, and communications; Financial Intermediation; Real estate activities; Public administration defense, and compulsory social security; Education; Communal and personal social services; Activities of households as employees of domestic personnel; Activities of extraterritorial organizations and bodies; and Other.
} 
specification because of perfect collinearity. Parameter identification in this case is obtained from the subsample of firms with more than one loan from the same bank in the same month. The addition of these interacted fixed effects help us to better differentiate between the two main theories of collateral by eliminating the selection effects by both firms and banks. That is, they compare the same firms at the same time borrowing from the same bank, so that there is no difference in signaling by the firms or collateral requirements by the banks related to firm risk. This leaves only the loss-mitigating effects and the risk-reduction incentive effects of collateral. To the extent that the coefficient on Collateral is negative, it provides support for the ex post theories, under which riskier borrowers for whom these lossmitigation and incentive effects are likely much larger.

In our fourth specification of equation (1), we add two additional loan characteristics: Amount and Maturity. We exclude these variables from our main specifications because they are potentially endogenous, as they may be determined simultaneously or even after the collateral decision. As shown below, the results do not change substantially with the inclusion of these terms.

We also run the four specifications of the Risk_Premium regressions using collateral characteristics and types to investigate the intensive margin. First, to test whether different collateral characteristics are more strongly associated with the different theories, we limit the sample to secured loans and differentiate between liquid and illiquid collateral using the following form:

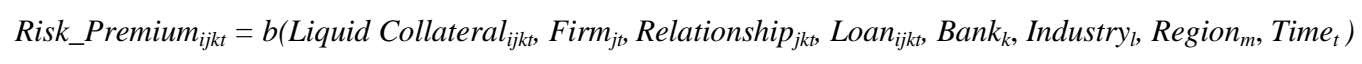

As noted above, Liquid Collateral takes a value of one when the collateral is either: Pledged Deposits, Bank Guarantees, or Securities. Other types of collateral are collectively treated as illiquid and constitute the omitted category. Loans with no collateral are excluded from this estimation. This regression allows us to determine whether Liquid Collateral and Illiquid Collateral have the same risk-collateral relation.

Next, we use both Liquid Collateral and Illiquid Collateral in the same specification and reexamine the full sample of loans, including those with no collateral pledged as the omitted category:

$$
\begin{array}{r}
\text { Risk_Premium }_{i j k t}=c\left(\text { Liquid Collateral }_{i j k}, \text { Illiquid Collateral }_{i j k}, \text { Firm }_{j}, \text { Relationship }_{j k t}, \text { Loan }_{i j k t}, \text { Bank }_{k}, \text { Industry }_{b}\right. \\
\text { Region } \left._{m}, \text { Time }_{t}\right)
\end{array}
$$


This specification allows us to see whether loans with Liquid Collateral and Illiquid Collateral are associated with higher or lower risk than loans with no collateral pledged.

Our final specifications of the Risk_Premium regressions use dummy variables for all nine types of collateral and include the full sample, using no collateral as the omitted category:

$$
\begin{aligned}
& \text { Risk_Premium }_{i j k t}=d\left(\text { Pledged Deposits }_{i j k} \text {, Bank Guarantees }{ }_{i j k t} \text {,Securities }{ }_{i j k} \text {, Creditor-Held Movable Assets }{ }_{i j k}\right. \text {, } \\
& \text { Debtor-Held Movable Assets }_{i j k t} \text {, Residential Real Estate }{ }_{i j k}, \text { Commercial Real Estate }_{i j k t}, \text { Collateral Bonds }_{i j k t}, \text { Vehicles }_{i j k t}
\end{aligned}
$$

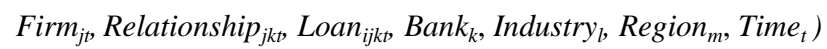

This specification allows us to see whether loans with different types of collateral are associated with higher or lower risk than loans with no collateral pledged.

We also run regressions using Ex_Post_Nonperformance $e_{i j k t}$ as a dependent variable. This variable indicates whether the loan eventually becomes delinquent or defaults, but does not measure the size of any losses. As above, this measure is separately regressed on Collateral using the full sample, Liquid using only secured loans, Liquid and Illiquid using the full sample, and all nine collateral types using the full sample:

$$
\begin{aligned}
& \text { Ex_Post_Nonperformance }{ }_{i j k t}=e\left(\text { Collateral }_{i j k t}, \text { Firm }_{j t}, \text { Relationship }_{j k t}, \text { Loan }_{i j k}, \text { Bank }_{k}, \text { Industry }_{b}, \text { Region }_{m}, \text { Time }_{t}\right)(5)
\end{aligned}
$$

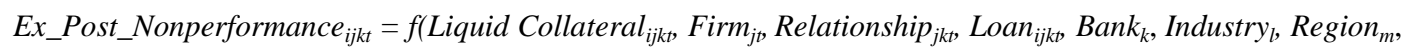

$$
\begin{aligned}
& \text { Time }_{t} \text { ) (6) } \\
& \text { Ex_Post_Nonperformance }{ }_{i j k t}=g\left({\text { Liquid } \text { Collateral }_{i j k t} \text {, Illiquid Collateral }}_{i j k t}, \text { Firm }_{j,}, \text { Relationship }_{j k t}, \text { Loan }_{i j k t}\right. \text {, } \\
& \text { Bank }_{k}, \text { Industry }_{,} \text {Region }_{m}, \text { Time }_{t} \text { ) (7) } \\
& \text { Ex_Post_Nonperformance }_{i j k t}=h\left(\text { Pledged Deposits }_{i j k t} \text {,Bank Guarantees } s_{i j k} \text {, Securities }{ }_{i j k}\right. \text {, Creditor-Held Movable } \\
& \text { Assets }_{i j k t}, \text { Debtor-Held Movable Assets } i_{i j k t} \text {, Residential Real Estate }{ }_{i j k t}, \text { Commercial Real Estate }_{i j k}, \text { Collateral Bonds }_{i j k} \text {, } \\
& \text { Vehicles }_{i j k}, \text { Firm }_{j}, \text { Relationship }_{j k}, \text { Loan }_{i j k}, \text { Bank }_{k}, \text { Industry }_{b}, \text { Region }_{m}, \text { Time }_{t} \text { ) (8) }
\end{aligned}
$$

For the analysis of Ex_Post_Nonperformance, we drop all loans that do not mature before the end of the sample (December 2003); thereby leaving 26,033 bank loans. Since this has the effect of reducing the average loan maturity in our sample, we also eliminate all loans originated during the last six months of the sample (July - December 2003) - further reducing the sample to 25,391 loans.

There are two important differences between the Ex_Post_Nonperformance and Risk_Premium regressions. First, the loss-mitigating effects of collateral are missing from these regressions because the 
dependent variable does not capture the size of any losses. Second, we cannot include firm fixed effects to control for unobserved borrower heterogeneity that may be correlated with collateral pledges. The reason is that we have very few nonperformance observations that are repeated for individual borrowers.

\section{Results}

Table 4 presents the results for the loan risk premium regressions for collateral overall and collateral characteristics. Columns I-III show the baseline specifications of equations (1), (2), and (3), which include only the collateral variables - Collateral in column (I), Liquid Collateral in column (II), and Liquid Collateral and Illiquid Collateral in column (III) - along with Installment, and the fixed effects for Region, Bank and Time. Columns IV-VI replicate columns I-III, except that additional controls are added for the past nonperformance of the firm (Prior_Default and Prior_NPL), legal structure of the firm (General Partnership, Limited Partnership, Joint Stock Company, and Limited Liability Corporation, with Sole Proprietorship as the omitted group), industry fixed effects (Industry), and relationship with the bank (Relationship Length). Columns VII-IX incorporate Firm $_{j}{ }^{*}$ Bank $_{k} *$ Time $_{t}$ fixed effects, while removing all time-invariant firm characteristics and relationship length, as well as the individual bank and time fixed effects. Finally, columns X-XII additionally control for two potentially endogenous loan contracts terms (Amount and Maturity). When only Liquid Collateral is included in columns II, V, VIII, and XI, only the subsample of secured loans is included.

Importantly, the borrower and lender selection effects highlighted in the ex ante and ex post theories are present only in columns I-VI, while the regressions in columns VII-XII virtually eliminate these effects, as parameters are identified by effectively comparing loans to the same borrower by the same lender at approximately the same point in time. Only the loss-mitigation and risk-reduction incentive effects of collateral are present in the latter columns.

Table 5 provides the results for the Ex_Post_Nonperformance regressions. The table is structured

like Table 4, except that we exclude the Firm $_{j} *$ Bank $_{k} *$ Time $_{t}$ fixed effects. As mentioned previously, we cannot estimate the Ex_Post_Nonperformance regressions using firm fixed effects because there are too 
few nonperformance observations that are repeated for individual borrowers. Also noted above, the sample for the Ex_Post_Nonperformance regressions is slightly smaller than that for the Risk_Premium regressions because we drop all loans that do not mature before the end of the sample and eliminate all loans originated during the last six months of the sample. Finally, as noted, the loss-mitigating effects of collateral are missing from these regressions because the dependent variable does not capture the size of any losses.

\section{A. Collateral Overall.}

The estimated relation between loan risk premiums and the overall incidence of collateral is displayed in columns I, IV, VII, and X of Table 4. In each of these regressions, we find a negative relation between the loan risk premiums and collateral. The results in column I suggest that collateral overall is associated with a 60 basis point discount. As discussed above, a negative coefficient has an ambiguous interpretation. It could reflect the lower inherent risks of the borrowers that signal their risk by choosing secured loan contracts under the ex ante theories. Alternatively, it could indicate that the ex post theories were more prevalent, but that the loss-mitigating effects of collateral and/or the riskreduction incentive effects more than offset the higher inherent risks of the secured borrowers. Moving from column I to column IV, we control for several firm characteristics and the coefficient remains close to -0.60 . In column VII, the lender and borrower selection effects are virtually eliminated by including Firm $_{j}{ }^{*}$ Bank $_{k} *$ Time $_{t}$ fixed effects. The coefficient on Collateral remains relatively constant. This suggests that the measured negative relations in columns I and IV are mainly driven by the loss-mitigation and risk-reduction incentive effects of collateral. This provides support for the ex post theories, under which riskier borrowers for whom these loss-mitigation and risk-reduction incentive effects are likely much larger.

We will return to Table 4 later to examine the effects of collateral characteristics, but we turn now to Table 5, which presents the marginal effects of Probit models for ExPost_Nonperformance In column I, the overall risk-collateral relation is positive, again suggesting the net empirical dominance of the ex post theories, given that lender selection effect of these theories is the only one that predicts a positive 
marginal effect. The marginal effects remain positive as we move from column I to columns IV and VII, controlling for firm and other loan characteristics. All in all, the results suggest that the ex post theories appear to dominate the ex ante theories in explaining the overall collateral decisions on the extensive margin.

\section{B. Liquid versus Illiquid Collateral}

We next turn to the investigation of the intensive margins by examining the estimated relation between both the loan risk premiums and ex post nonperformance and whether liquid or illiquid collateral is pledged. In columns II, V, VIII, and XI of Table 4, we drop the unsecured loans and estimate the effect of liquid versus illiquid collateral on Risk_Premium by including Liquid Collateral and using Illiquid Collateral as the omitted category. In these regressions, we find that the incidence of Liquid Collateral is associated with lower loan risk premiums and this is maintained when the two selection effects are virtually absorbed by the fixed effects. This suggests that the loss mitigation and risk shifting effects of collateral under the ex post theories apply more strongly to those pledging Liquid Collateral than Illiquid Collateral. This is consistent with the intuition that liquid collateral is more desired by lenders to reduce their exposures to risky borrowers.

Analyzing Ex_Post_Nonperformance in columns II, V, and VIII of Table 5, we find that loans secured by Liquid Collateral become delinquent or default less often than those with Illiquid Collateral. This is consistent with borrowers having greater incentives not to lose the more desirable liquid collateral. Similarly, lenders may have greater incentives to enforce their security interests and resist renegotiation pressures when collateral is liquid and can be sold quicker with smaller discounts in secondary markets.

To investigate the intensive margin further, we turn to the Risk_Premium regressions in columns III, VI, IX, and XII in Table 4using the full sample; and where dummies of Liquid Collateral and Illiquid Collateral are specified and no collateral is the omitted category. Here, we consistently see negative coefficients for both Liquid Collateral and Illiquid Collateral but with much larger magnitudes for Liquid Collateral. These effects persist with the inclusion of Firm $_{j} *$ Bank $_{k} *$ Time $_{t}$ fixed effects; thereby suggesting that the ex post theories empirically dominate the ex ante theories for both liquid and illiquid 
collateral. The coefficients on Liquid Collateral and Illiquid Collateral are also statistically significantly different from one another at the one percent level in all cases (t-statistics not shown). This also suggests that the specification accounting for collateral characteristics, like liquidity, is superior to the common method of just considering collateral overall.

In Table 5, columns III, VI, and IX, the marginal effects of Liquid Collateral are negative and the marginal effects of Illiquid Collateral are positive in the Ex_Post_Nonperformance regressions. The difference is statistically significant at the one percent level in all cases (t-tests not shown). This is again consistent with the intuition that the risk-reduction incentive of liquid collateral is stronger than that of illiquid collateral.

Turning to the other explanatory variables in Tables 4 and 5, we see that Prior_NPL is positively related to both Risk_Premium and Ex_Post_Nonperformance as expected, but the signs of Prior_Default are conflicting in the Ex_Post_Nonperformance regressions, perhaps owing to the small number of loans to firms that had recently defaulted and received new credit. Relative to sole proprietorships, each of the other ownership structures are generally associated with lower loan risk premiums, although the signs are again conflicting in the Ex_Post_Nonperformance regressions. Longer banking relationships appear to be associated with higher loan risk premiums and lower rates of ex post nonperformance (although the latter is not always statistically significant), the former being consistent with "lock-in effects" in which lenders exert market power over relationship borrowers (e.g., Rajan, 1992). Riskier firms are more likely to have installment loans, as they are associated with higher loan risk premiums and higher rates of ex post nonperformance.

\section{Collateral Types}

In our final analysis, we specify all nine collateral types identified in the dataset, using no collateral as the omitted category. The results are reported in Table 6. The first four columns of the table

report corresponding specifications for the Risk_Premium regressions in Table 4, while the last three columns report the corresponding specifications for the Ex_Post_Nonperformance regressions in Table 5. 
The Risk_Premium regressions in Table 6 show substantial differences across collateral types. Some types show negative coefficients across all specifications (e.g., Pledged Deposits), consistent with the empirical dominance of the ex post theories. Others show negative coefficients for the first two specifications, which become statistically insignificant when the Firm*Bank*Time terms are included (e.g., Commercial Real Estate), supporting the dominance of the ex ante theories. The Ex_Post_Nonperformance show even more differences across collateral types, with most of the liquid collateral types being associated with lower ex post nonperformance and most of the illiquid collateral types being associated with higher ex post nonperformance. The heterogeneity of both sets of results suggest that exploiting information about collateral types can uncover subtle relationships with borrower risk.

\section{Robustness Tests}

Our empirical results in Tables 4, 5, and 6 are robust to two additional checks. Our most conservative specifications above with the Firm*Bank*Time fixed effects in Tables 4 and 6 are estimated for a subsample of firms with multiple loans from the same bank in the same month $(13,274$ loans). In the specifications where identification of parameters is obtained from the intensive margin (i.e., within secured loans) we further require that firms have multiple secured loans from the same bank in the same month (4,989 loans). This raises the question of whether the results in Tables 4 and 6 for the larger sample - those without the Firm*Bank*Time fixed effects -- are robust to using these smaller samples of loans. Re-estimating the regressions with these sub-samples yields Collateral coefficients that are very similar those reported above. These results are not shown for brevity and are available upon request.

Next, we re-estimate our main specifications after dropping all loans that appear to be continuations of previous loans. (Loans designated in the registry as renegotiations have already been excluded from our analysis.) Including continuations of previous loans could bias the estimated relations between ex post nonperformance and collateral. This bias would arise in situations in which the borrower became distressed and the bank demanded that collateral is pledged, but recorded the adjustment as a new 
loan with overdue payments. To identify such situations, we look for loans that are originated right after another loan at the same bank terminates and the two loans have the same contract amounts. We identify 2,184 such loans. Re-estimating the specification in Tables 4 and 5 after dropping for this sub-sample has virtually no effect on the results: the signs, size, and statistical significance of all collateral coefficients remains unchanged. These results are also not shown for brevity and are available upon request.

\section{Conclusions}

Economic theory suggests that collateral pledges may be associated with either higher or lower risk. One strand of theory focuses on ex ante private information and suggests that collateral may allow lenders to sort observationally equivalent loan applicants through signaling. A second set of theories motivates collateral as part of an optimal debt contract by invoking ex post frictions, like moral hazard, and predicts that observably riskier borrowers are more likely to be required by lenders to pledge collateral.

The empirical literature has found that loan risk and collateral are sometimes found to be positively related and other times found to be negatively related. This paper offers a potential solution to this puzzle by highlighting variations in the risk-collateral relation depending on the role of the economic characteristics of collateral, like liquidity, as well as collateral types. Hence, certain economic characteristics or types of collateral may be more strongly associated with the different theories.

Using credit registry data and a novel identification strategy to control for borrower and lender selection effects allows us to differentiate between the ex ante and ex post theories of collateral. We find that the data on collateral overall is associated with the empirical dominance of the ex post theories on the extensive margin. Liquid and illiquid collateral have somewhat different relations with our risk measures, indicating somewhat different levels of support for the theories on the intensive margin. We also find that

individual collateral types exhibit significant variation in terms of risk-collateral relations, with some consistent with ex ante theories and others with ex post theories. 
Collateral does not appear to be homogeneous in its economic effects, and hence future research should include information about the economic characteristics and/or types of collateral whenever possible. 


\section{References}

Agarwal, Sumit and Robert Hauswald (2010). "Distance and Private Information in Lending," Review of Financial Studies, 23(7), 2757-2788.

Aghion, Philippe and Patrick Bolton (1997). "A Theory of Trickle-Down Growth and Development," Review of Economic Studies, 64, 151-172.

Albuquerque, Rui and Hugo A. Hopenhayn (2004). "Optimal Lending Contracts and Firm Dynamics," Review of Economic Studies, 71, 285-315.

Banerjee, Abhijit V. and Andrew F. Newman (1993). "Occupational Choice and the Process of Development," Journal of Political Economy, 101, 274-298.

Benmelech, Efraim and Nittai Bergman (2008). "Liquidation Values and the Credibility of Financial Contact Renegotiation: Evidence from U.S. Airlines," Quarterly Journal of Economics, 123(4), 16351677.

Benmelech, Efraim and Nittai Bergman (2009). "Collateral Pricing," Journal of Financial Economics, 91(3), 339-360.

Benmelech, Efraim and Nittai Bergman (2011). "Bankruptcy and the Collateral Channel," Journal of Finance, 66(2), 337-378.

Benmelech, Efraim, Mark Germaise, and Tobias Moskowitz (2005). "Do Liquidation Values Affect Financial Contracts?: Evidence from Commercial Loan Contracts and Zoning Regulations," Quarterly Journal of Economics, 120(3), 1121-1154.

Berger, Allen N., W. Scott Frame, and Vasso Ioannidou (2011). "Tests of Ex Ante versus Ex Post Theories of Collateral using Private and Public Information," Journal of Financial Economics, 100(1), 8597.

Berger, Allen N. and Gregory F. Udell (1990). "Collateral, Loan Quality, and Bank Risk," Journal of Monetary Economics, 25, 21-42.

Berger, Allen N. and Gregory F. Udell (1995). "Relationship Lending and Lines of Credit in Small Firms," Journal of Business, 68, 351-381.

Bernanke, Ben S. and Mark Gertler (1989). "Agency Costs, Net Worth, and Business Fluctuations," American Economic Review, 79, 14-31.

Bernanke, Ben S. and Mark Gertler (1990). "Financial Fragility and Economic Performance," Quarterly Journal of Economics, 105, 87-114.

Besanko, David and Anjan V. Thakor (1987a). "Collateral and Rationing: Sorting Equilibria in Monopolistic and Competitive Credit Markets," International Economic Review, 28, 671-689.

Besanko, David and Anjan V. Thakor (1987b). "Competitive Equilibrium in the Credit Market under Asymmetric Information," Journal of Economic Theory, 42, 167-183. 
Bester, Helmut (1985). "Screening vs. Rationing in Credit Markets with Imperfect Information," American Economic Review, 75, 850-855.

Bester, Helmut (1987). "The Role of Collateral in Credit Markets with Imperfect Information," European Economic Review, 106, 60-75.

Blackwell, David W. and Drew B. Winters (1997). "Banking Relationships and the Channel of Monitoring on Loan Pricing," Journal of Financial Research, 20, 275-289.

Boot, Arnoud W.A. and Anjan V. Thakor (1994). "Moral Hazard and Secured Lending in an Infinitely Repeated Credit Market Game,” International Economic Review, 35, 899-920.

Boot, Arnoud W.A., Anjan V. Thakor, and Gregory F. Udell (1991). "Secured Lending and Default Risk: Equilibrium Analysis, Policy Implications and Empirical Results," Economic Journal, 101, 458-472.

Boyd, John H. and Bruce D. Smith (1994). "The Equilibrium Allocation of Investment Capital in the Presence of Adverse Selection and Costly State Verification," Economic Theory, 3, 427-451.

Boz, Emine and Enrique Mendoza (2014). "Financial Innovation, the Discovery of Risk, and the U.S. Credit Crisis," Journal of Monetary Economics, 62, 1-22.

Brick, Ivan E. and Darius Palia (2007). "Evidence of Jointness in the Terms of Relationship Lending," Journal of Financial Intermediation, 16, 452-476.

Cerqueiro, Geraldo, Steven Ongena, and Kasper Roszbach (forthcoming). "Collateralization, Bank Loan Rates and Monitoring," Journal of Finance.

Chan and Kanatas (1985). "Asymmetric Valuations and the Role of Collateral in Loan Agreements," Journal of Money, Credit, and Banking, 17, 84-95.

Chan, Yuk-Shee, and Anjan V. Thakor (1987). "Collateral and Competitive Equilibria with Moral Hazard and Private Information,” Journal of Finance, 42, 345-363.

Cooley, Thomas, Ramon Marimon, and Vincenzo Quadrini (2004). “Aggregate Consequences of Limited Contract Enforceability," Journal of Political Economy, 112, 817-847.

Degryse, Hans and Patrick Van Cayseele (2000). "Relationship Lending within a Bank-Based System: Evidence from European Small Business Data," Journal of Financial Intermediation, 9, 90-109.

Gale, Douglas and Martin Hellwig (1985). "Incentive-Compatible Debt Contracts: The One-Period Problem," Review of Economic Studies, 52, 647-663.

Godlewski, Christophe and Laurent Weill (2011). "Does Collateral Help Mitigate Adverse Selection? A Cross-Country Analysis," Journal of Financial Services Research, 40, 49-78.

Gan, Jie. (2007). "Collateral, Debt Capacity, and Corporate Investment: Evidence from a Natural Experiment," Journal of Financial Economics, 85, 709-734.

Gorton, Gary and Guillermo Ordonez (2014). "Collateral Crises," American Economic Review, 104, 343378. 
Holmstrom, Bengt and Jean Tirole (1997). "Financial Intermediation, Loanable Funds, and the Real Sector," Quarterly Journal of Economics, 62, 663-691.

Honohan, Patrick (2007). "Dollarization and Exchange Rate Fluctuations", CEPR discussion paper DP6205.

Inderst, Roman and Holger M. Mueller (2007). "A Lender-Based Theory of Collateral, Journal of Financial Economics, 84, 826-839.

Ioannidou, Vasso and Steven Ongena (2010). "Time for a Change: Loan Conditions and Bank Behavior When Firms Switch Banks," Journal of Finance, 65(5), 1847-1878.

Jimenez, Gabriel and Jesus Saurina (2004). "Collateral, Type of Lender and Relationship Banking as Determinants of Credit Risk," Journal of Banking and Finance, 28, 2191-2212.

John, Kose, Anthony Lynch, and Manju Puri (2003). "Credit Ratings, Collateral, and Loan Characteristics: Implications for Yield," Journal of Business, 76, 371-409.

Khwaja, Aslim and Atif Mian (2008). "Tracing the Impact of Liquidity Shocks: Evidence from an Emerging Market," American Economic Review, 98, 1413-1442.

Kiyatoki, Nobuhiro and John Moore (1997). "Credit Cycles," Journal of Political Economy, 105, 211248.

Lehmann, Erik and Doris Neuberger (2001). "Do Lending Relationships Matter? Evidence from Bank Survey Data in Germany," Journal of Economic Behavior and Organization, 45, 339-359.

Liberti, Jose Maria and Jason Sturgess (2014). "Uncovering Collateral Constraints," working paper. Available at: http://papers.ssrn.com/sol3/papers.cfm?abstract_id=2407959.

Machauer, Achim and Martin Weber (1998). "Bank Behavior Based on Internal Credit Ratings of Borrowers," Journal of Banking and Finance, 22, 1355-1383.

Manove, Michael, A. Jorge Padilla, Marco Pagano (2001). "Collateral versus Project Screening: A Model of Lazy Banks," Rand Journal of Economics, 32, 726-744.

Menkhoff, Lukas, Doris Neuberger, and Ornsiri Rungruxsirivorn (2012). "Collateral and its Substitutes in Emerging Markets’ Lending,” Journal of Banking and Finance, 36, 817-834.

Rajan, Raghuram (1992). "Insiders and Outsiders: The Choice between Informed and Arms Length Debt," Journal of Finance, 47, 1367-1400.

Schnabl, Philipp (2012). "The International Transmission of Bank Liquidity Shocks: Evidence from an Emerging Market," Journal of Finance, 67, 897-932.

Sirtaine, Sophie, Ilias Skamnelos, and Sissy Frank (2004). Bolivia: Challenges in the Corporate and Banking Sectors, World Bank: Washington DC.

Townsend, Robert M. (1979). "Optimal Contracts and Competitive Markets with Costly State Verification," Journal of Economic Theory, 21, 265-293. 
Voordeckers, Wim and Tensie Steijvers (2006). "Business Collateral and Personal Commitments in SME Lending," Journal of Banking and Finance, 30: 3067-3086.

Williamson, Stephen D. (1986). "Costly Monitoring, Financial Intermediation and Equilibrium Credit Rationing," Journal of Monetary Economics, 18, 159-179.

World Bank (2005) “Bolivia Country Economic Memorandum," Report No. 32233-BO, Washington DC. 


\section{Table 1: Variables and Summary Statistics}

The table reports the names, definitions, and summary statistics (observations, means, and standard deviations) of variables used in the analysis. The summary statistics for the collateral types and characteristics are based only on the set of loans for which collateral is pledged. The summary statistics for Ex_Post_Nonperformance use the number of loans that matured before the end of the sample period. The summary statistics for all other variables are based on the full sample of loans.

\begin{tabular}{|c|c|c|c|c|}
\hline Variables & Description & Obs & Mean & St. Dev. \\
\hline \multicolumn{5}{|l|}{ Loan Characteristics } \\
\hline Interest Rate & Annual contractual interest rate at loan origination & 28,252 & 13.538 & 2.848 \\
\hline Maturity & Number of months between loan origination and maturity & 28,252 & 10.757 & 12.833 \\
\hline Risk_Premium & Loan interest rate minus U.S. Treasury rate of comparable maturity at origination & 28,252 & 9.507 & 2.557 \\
\hline Amount & Loan amount at loan origination in US dollars & 28,252 & 148,902 & 436,026 \\
\hline Installment & Equals one if an installment loan and zero if a discount loan & 28,252 & 0.456 & 0.498 \\
\hline Collateral & Equals one if collateral was pledged at loan origination, and is zero otherwise & 28,252 & 0.177 & 0.381 \\
\hline \multicolumn{5}{|l|}{ Types of Collateral } \\
\hline Pledged Deposits & Equals one if deposits were pledged, and is zero otherwise & 4,989 & 0.091 & 0.287 \\
\hline Bank Guarantees & $\begin{array}{l}\text { Equals one if bank guarantees or letters of credit were pledged, and is } \\
\text { zero otherwise }\end{array}$ & 4,989 & 0.037 & 0.188 \\
\hline Securities & Equals one if bonds or stocks were pledged, and is zero otherwise & 4,989 & 0.022 & 0.146 \\
\hline Creditor-Held Movable Assets & $\begin{array}{l}\text { Equals one if there is a possessory security on the firm's movable assets (e.g., } \\
\text { inventory, crops, properties, tools, and equipment), and is zero otherwise }\end{array}$ & 4,989 & 0.158 & 0.364 \\
\hline Debtor-Held Movable Assets & $\begin{array}{l}\text { Equals one if there is a non-possessory security on the firm's movable as sets } \\
\text { (e.g., a/cs receivable, inventory, crops, properties, tools, and equipment), } \\
\text { and is zero otherwise }\end{array}$ & 4,989 & 0.248 & 0.432 \\
\hline Residential Real Estate & Equals one if a residential real estate is pledged, and is zero otherwise & 4,989 & 0.199 & 0.399 \\
\hline Commercial Real Estate & Equals one if a commercial real estate is pledged, and is zero otherwise & 4,989 & 0.088 & 0.283 \\
\hline Collateral Bonds & $\begin{array}{l}\text { Equals one if a loan is secured with endorsements from deposit warehouses } \\
\text { backed by the deposit of commodities ("Bonos de Prenda"). }\end{array}$ & 4,989 & 0.135 & 0.342 \\
\hline Vehicles & Equals one if vehicles were pledged, and is zero otherwise & 4,989 & 0.023 & 0.149 \\
\hline \multicolumn{5}{|l|}{ Collateral Characteristics } \\
\hline Liquid Collateral & $\begin{array}{l}\text { Equals one if the type of collateral pledged is deposits, bank guarantees, } \\
\text { or securities, and is zero otherwise }\end{array}$ & 4,989 & 0.149 & 0.356 \\
\hline Illiquid Collateral & Equals one if the type of collateral pledged is not liquid, and is zero otherwise & 4,989 & 0.851 & 0.356 \\
\hline \multicolumn{5}{|l|}{ Past Nonperformance } \\
\hline Prior_Default & $\begin{array}{l}\text { Equals one if the borrower had defaulted on a loan anytime in the previous } \\
12 \text { months with any lender, and is zero otherwise }\end{array}$ & 28,252 & 0.003 & 0.052 \\
\hline Prior_NPL & $\begin{array}{l}\text { Equals one if the borrower had overdue payments of at least } 30 \text { days with } \\
\text { any bank anytime in the previous } 12 \text { months, and is zero otherwise }\end{array}$ & 28,252 & 0.211 & 0.408 \\
\hline \multicolumn{5}{|l|}{ Legal Structure of the Firm } \\
\hline Sole Proprietorship & Equals one if the firm is a sole proprietorship, and is zero otherwise & 28,252 & 0.126 & 0.332 \\
\hline General Partnership & $\begin{array}{l}\text { Equals one if the firm is a general partnership (i.e., all partners have unlimited } \\
\text { liability and ownership is not transferable), and is zero otherwise }\end{array}$ & 28,252 & 0.008 & 0.091 \\
\hline Limited Partnership & $\begin{array}{l}\text { Equals one if the firms is a limited partnership (i.e., some partners have limited } \\
\text { liability and their ownership rights are transferable), and is zero otherwise }\end{array}$ & 28,252 & 0.136 & 0.343 \\
\hline Joint Stock Company & $\begin{array}{l}\text { Equals one if the firm is a joint stock company (i.e., all partners have unlimited } \\
\text { liability and their ownership rights are transferable), and is zero otherwise }\end{array}$ & 28,252 & 0.222 & 0.415 \\
\hline Limited Liability Company & $\begin{array}{l}\text { Equals one if the firm is a limited liability company (i.e., all partners have limited } \\
\text { liability and transferable ownership rights), and is zero otherwise }\end{array}$ & 28,252 & 0.488 & 0.500 \\
\hline \multicolumn{5}{|l|}{ Relationship Characteristic } \\
\hline Rel_Length & Length of bank-firm relationship in months & 28,252 & 22.704 & 15.769 \\
\hline \multicolumn{5}{|l|}{ Ex Post Loan Performance } \\
\hline Ex_Post_Nonperformance & $\begin{array}{l}\text { Equals one if a loan is } 30+\text { days overdue anytime after origination or if it is } \\
\text { downgraded to the default status (a rating of 5) and zero otherwise }\end{array}$ & 25,983 & 0.059 & 0.236 \\
\hline
\end{tabular}




\section{Table 2: Risk Premium, Ex Post Nonperformance, and Collateral}

The table reports the summary statistics (observations, means, and standard deviations) for the dependent variables Risk_Premium and Ex_Post_Nonperformance for loans with and without collateral, for loans secured with liquid and illiquid collateral, and those secured by nine different types of collateral.

\begin{tabular}{lrrrrrr}
\hline \hline & \multicolumn{3}{c}{ Risk_Premium } & \multicolumn{3}{c}{ Ex_Post_Nonperformance } \\
& Obs & Mean & St. Dev. & Obs & Mean & St. Dev. \\
\hline & & & & & & \\
No Collateral & 23,263 & 9.651 & 2.412 & 23,263 & 0.050 & 0.217 \\
Collateral & 4,989 & 8.839 & 3.062 & 4,989 & 0.083 & 0.276 \\
& & & & & & \\
Liquid Collateral & 745 & 8.302 & 3.081 & 745 & 0.027 & 0.162 \\
Illiquid Collateral & 4,244 & 8.933 & 3.049 & 4,244 & 0.093 & 0.291 \\
& & & & & & \\
Pledged Deposits & 452 & 8.646 & 2.965 & 452 & 0.020 & 0.140 \\
Bank Guarantees & 184 & 6.631 & 3.193 & 184 & 0.027 & 0.163 \\
Securities & 109 & 9.695 & 2.052 & 109 & 0.055 & 0.229 \\
Creditor-Held Movable Assets & 786 & 6.750 & 2.839 & 786 & 0.095 & 0.294 \\
Debtor-Held Movable Assets & 1,239 & 8.809 & 3.169 & 1,239 & 0.103 & 0.303 \\
Residential Real Estate & 992 & 10.478 & 2.529 & 992 & 0.089 & 0.284 \\
Commercial Real Estate & 439 & 9.427 & 2.717 & 439 & 0.100 & 0.301 \\
Collateral Bonds & 675 & 9.068 & 2.552 & 675 & 0.074 & 0.262 \\
Vehicles & 113 & 9.194 & 2.066 & 113 & 0.106 & 0.309 \\
\hline \hline
\end{tabular}


Table 3: Correlation Matrix

The table reports correlations among the key variables used in the analysis.

\begin{tabular}{|c|c|c|c|c|c|c|c|c|c|c|c|c|c|c|c|}
\hline & & [1] & [2] & [3] & [4] & [5] & {$[6]$} & [7] & {$[8]$} & [9] & {$[10]$} & {$[11]$} & {$[12]$} & [13] & [14] \\
\hline Risk_Premium & [1] & 1 & & & & & & & & & & & & & \\
\hline Ex_Post_Nonperformance & [2] & 0.083 & 1 & & & & & & & & & & & & \\
\hline Collateral & {$[3]$} & -0.121 & 0.056 & 1 & & & & & & & & & & & \\
\hline Liquid Collateral & {$[4]$} & -0.078 & -0.021 & 0.355 & 1 & & & & & & & & & & \\
\hline Illiquid Collateral & {$[5]$} & -0.094 & 0.069 & 0.908 & -0.069 & 1 & & & & & & & & & \\
\hline Pledged Deposits & {$[6]$} & -0.043 & -0.020 & 0.275 & 0.775 & -0.054 & 1 & & & & & & & & \\
\hline Bank Guarantees & [7] & -0.091 & -0.010 & 0.175 & 0.492 & -0.034 & -0.010 & 1 & & & & & & & \\
\hline Securities & {$[8]$} & 0.005 & 0.000 & 0.134 & 0.378 & -0.026 & -0.008 & -0.01 & 1 & & & & & & \\
\hline Creditor-Held Movable Assets & {$[9]$} & -0.182 & 0.030 & 0.365 & -0.028 & 0.402 & -0.022 & -0.01 & -0.011 & 1 & & & & & \\
\hline Debtor-Held Movable Assets & {$[10]$} & -0.059 & 0.044 & 0.463 & -0.035 & 0.509 & -0.027 & -0.02 & -0.013 & -0.036 & 1 & & & & \\
\hline Residential Real Estate & {$[11]$} & 0.072 & 0.028 & 0.412 & -0.031 & 0.454 & -0.024 & -0.02 & -0.012 & -0.032 & -0.041 & 1 & & & \\
\hline Commercial Real Estate & {$[12]$} & -0.004 & 0.025 & 0.271 & -0.021 & 0.299 & -0.016 & -0.01 & -0.008 & -0.021 & -0.027 & -0.02 & 1 & & \\
\hline Collateral Bonds & {$[13]$} & -0.027 & 0.013 & 0.338 & -0.026 & 0.372 & -0.020 & -0.01 & -0.010 & -0.027 & -0.034 & -0.03 & -0.020 & 1 & \\
\hline Vehicles & [14] & -0.008 & 0.014 & 0.137 & -0.010 & 0.151 & -0.008 & -0.01 & -0.004 & -0.011 & -0.014 & -0.01 & -0.008 & -0.010 & 1 \\
\hline
\end{tabular}




\section{Table 4: Determinants of Loan Risk Premiums}

This table reports OLS regressions for Risk_Premium $i j$, defined as the loan interest rate at origination minus the rate of U.S. Treasury securities with comparable maturity. Standard errors are corrected for heteroskedasticity using White standard errors and are reported in parentheses. ${ }^{* * *}, * *$, and $*$ indicate significance at the $1 \%, 5 \%$, and $10 \%$, respectively.

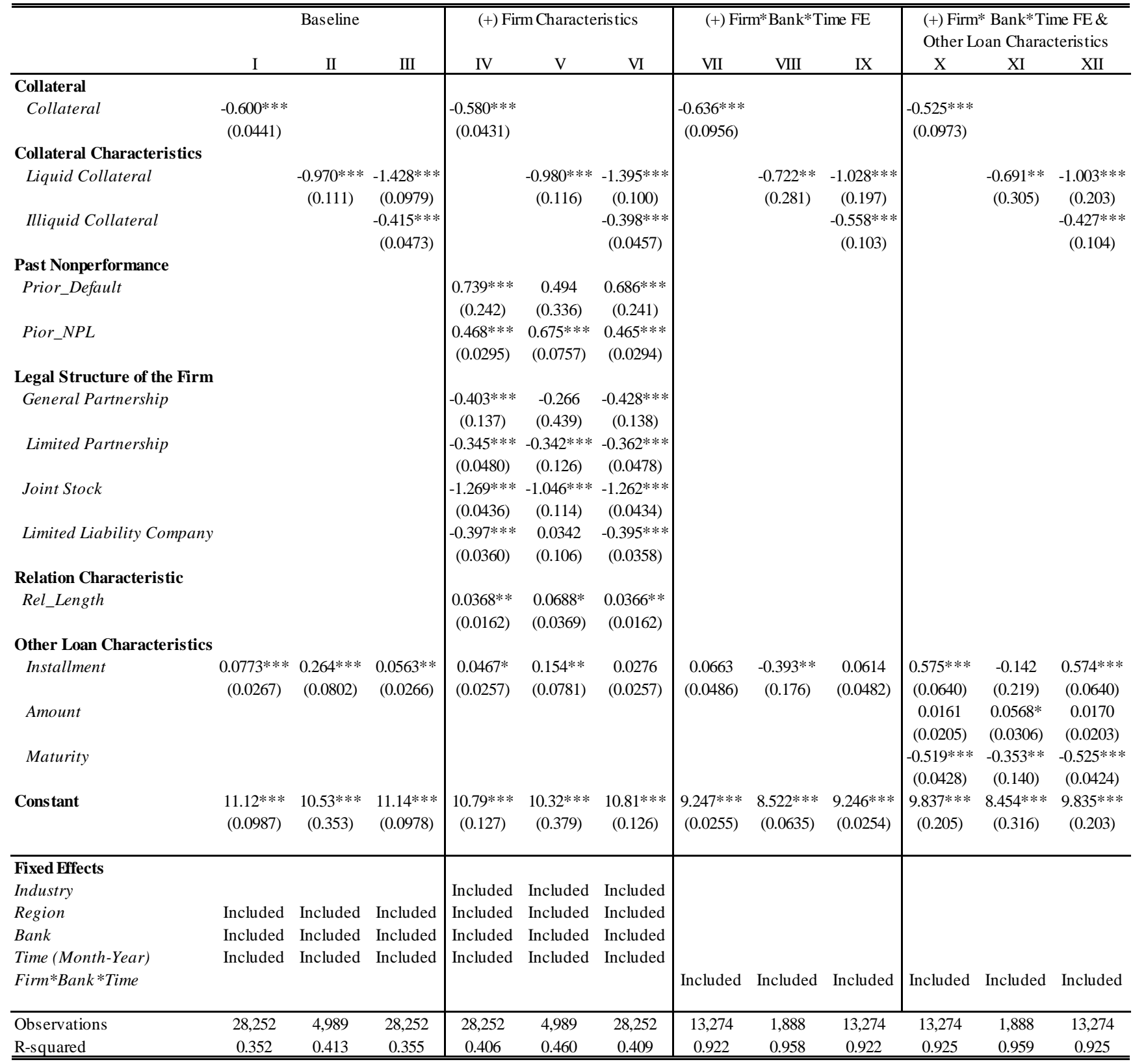




\section{Table 5: Determinants of Ex Post Nonperformance}

This table reports the marginal effects of Probit regressions for Ex_Post_Nonperformance, a dummy variable that equals one if a loan is 30+ days overdue any time after origination or if it is downgraded to the default status (i.e., given a rating of 5). For continuous variables, we report the effect for an infinitesimal change in each independent variable and for dummy variables we report the estimated effect of a change from 0 to 1 , evaluated at the mean of all independent variables. Standard errors are corrected for heteroskedasticity using White standard errors and are reported in parentheses. $* * *, * *$, and $*$ indicate significance at the $1 \%, 5 \%$, and $10 \%$, respectively.

\begin{tabular}{|c|c|c|c|c|c|c|c|c|c|}
\hline & \multicolumn{3}{|c|}{ Baseline } & \multicolumn{3}{|c|}{ (+) Firm Characteristics } & \multicolumn{3}{|c|}{$\begin{array}{l}\text { (+) Firm Characteristics \& } \\
\text { Other Loan Characteristics }\end{array}$} \\
\hline & $\mathrm{I}$ & II & III & IV & $\mathrm{V}$ & VI & VII & VIII & IX \\
\hline \multicolumn{10}{|l|}{ Collateral } \\
\hline Collateral & $\begin{array}{c}0.0350 * * * \\
(0.00478)\end{array}$ & & & $\begin{array}{c}0.0283^{* * *} \\
(0.00460)\end{array}$ & & & $\begin{array}{r}0.0281 * * * \\
(0.00468)\end{array}$ & & \\
\hline \multicolumn{10}{|l|}{ Collateral Characteristics } \\
\hline $\begin{array}{l}\text { Liquid Collateral } \\
\text { Illiquid Collateral }\end{array}$ & & $\begin{array}{c}-0.0636 * * * \\
(0.00772)\end{array}$ & $\begin{array}{c}-0.0162 * * \\
(0.00691) \\
0.0447 * * * \\
(0.00554)\end{array}$ & & $\begin{array}{c}-0.0532 * * * \\
(0.00741)\end{array}$ & $\begin{array}{c}-0.0131 * * \\
(0.00664) \\
0.0356 * * * \\
(0.00529)\end{array}$ & & $\begin{array}{c}-0.0511 * * * \\
(0.00711)\end{array}$ & $\begin{array}{c}-0.0123 * \\
(0.00674) \\
0.0353 * * * \\
(0.00540)\end{array}$ \\
\hline \multicolumn{10}{|l|}{ Past Nonperformance } \\
\hline Prior_Default & & & & $\begin{array}{c}0.0202 \\
(0.0255)\end{array}$ & $\begin{array}{c}-0.0480 * * * \\
(0.0170)\end{array}$ & $\begin{array}{c}0.0182 \\
(0.0248)\end{array}$ & $\begin{array}{c}0.0175 \\
(0.0246)\end{array}$ & $\begin{array}{c}-0.0463^{* * *} * \\
(0.0154)\end{array}$ & $\begin{array}{c}0.0157 \\
(0.0240)\end{array}$ \\
\hline Pior_NPL & & & & $\begin{array}{c}0.0613 * * * \\
(0.00438)\end{array}$ & $\begin{array}{c}0.0895^{* * *} \\
(0.0119)\end{array}$ & $\begin{array}{c}0.0609 * * * \\
(0.00436)\end{array}$ & $\begin{array}{c}0.0627 * * * \\
(0.00443)\end{array}$ & $\begin{array}{c}0.0868 * * * \\
(0.0118)\end{array}$ & $\begin{array}{c}0.0623 * * * \\
(0.00441)\end{array}$ \\
\hline \multicolumn{10}{|l|}{ Legal Structure of the Firm } \\
\hline General Partnership & & & & $\begin{array}{l}-0.0117 \\
(0.0104)\end{array}$ & $\begin{array}{c}0.0551 \\
(0.0663)\end{array}$ & $\begin{array}{l}-0.0123 \\
(0.0101)\end{array}$ & $\begin{array}{c}-0.0141 \\
(0.00977)\end{array}$ & $\begin{array}{c}0.0681 \\
(0.0729)\end{array}$ & $\begin{array}{l}-0.0145 \\
(0.00955)\end{array}$ \\
\hline Limited Partnership & & & & $\begin{array}{c}0.0156^{* * *} * \\
(0.00590)\end{array}$ & $\begin{array}{l}0.00738 \\
(0.0148)\end{array}$ & $\begin{array}{l}0.0146 * * \\
(0.00582)\end{array}$ & $\begin{array}{c}0.0165^{* * *} * \\
(0.00596)\end{array}$ & $\begin{array}{c}0.0149 \\
(0.0155)\end{array}$ & $\begin{array}{c}0.0155^{* * *} \\
(0.00588)\end{array}$ \\
\hline Joint Stock & & & & $\begin{array}{l}-0.00566 \\
(0.00422)\end{array}$ & $\begin{array}{c}-0.0358^{* * * *} \\
(0.0110)\end{array}$ & $\begin{array}{l}-0.00545 \\
(0.00422)\end{array}$ & $\begin{array}{l}-0.00233 \\
(0.00446)\end{array}$ & $\begin{array}{l}-0.0166 \\
(0.0120)\end{array}$ & $\begin{array}{l}-0.00219 \\
(0.00446)\end{array}$ \\
\hline Limited Liability Company & & & & $\begin{array}{c}0.00820 * * \\
(0.00391)\end{array}$ & $\begin{array}{c}0.0177 \\
(0.0127)\end{array}$ & $\begin{array}{c}0.00807 * * \\
(0.00389)\end{array}$ & $\begin{array}{c}0.00896 * * \\
(0.00390)\end{array}$ & $\begin{array}{c}0.0202 \\
(0.0127)\end{array}$ & $\begin{array}{c}0.00880 * * \\
(0.00389)\end{array}$ \\
\hline \multicolumn{10}{|l|}{ Relation Characteristic } \\
\hline Rel_Length & & & & $\begin{array}{l}-0.00133 \\
(0.00159)\end{array}$ & $\begin{array}{c}0.00893 * * \\
(0.00418)\end{array}$ & $\begin{array}{l}-0.00135 \\
(0.00159)\end{array}$ & $\begin{array}{l}-0.00112 \\
(0.00159)\end{array}$ & $\begin{array}{c}0.0106 * * * \\
(0.00406)\end{array}$ & $\begin{array}{l}-0.00113 \\
(0.00159)\end{array}$ \\
\hline \multicolumn{10}{|l|}{ Other Loan Characteristics } \\
\hline Installment & $\begin{array}{c}0.0244 * * * \\
(0.00291)\end{array}$ & $\begin{array}{c}0.0431 * * * \\
(0.00967)\end{array}$ & $\begin{array}{c}0.0231 * * * \\
(0.00290)\end{array}$ & $\begin{array}{c}0.0224 * * * \\
(0.00270)\end{array}$ & $\begin{array}{c}0.0379 * * * \\
(0.00893)\end{array}$ & $\begin{array}{c}0.0215 * * * \\
(0.00269)\end{array}$ & $\begin{array}{c}0.0169 * * * \\
(0.00347)\end{array}$ & $\begin{array}{c}0.0497 * * * \\
(0.0105)\end{array}$ & $\begin{array}{c}0.0164 * * * \\
(0.00345)\end{array}$ \\
\hline Amount & & & & & & & $\begin{array}{c}-0.00376 * * * \\
(0.000891)\end{array}$ & $\begin{array}{l}-0.0195^{* * *} \\
(0.00248)\end{array}$ & $\begin{array}{c}-0.00367 * * * \\
(0.000889)\end{array}$ \\
\hline Maturity & & & & & & & $\begin{array}{c}0.00493 * * \\
(0.00200)\end{array}$ & $\begin{array}{l}-0.00458 \\
(0.00519)\end{array}$ & $\begin{array}{c}0.00454 * * \\
(0.00200)\end{array}$ \\
\hline \multicolumn{10}{|l|}{ Fixed Effects } \\
\hline Industry & & & & Included & Included & Included & Included & Included & Included \\
\hline Region & Included & Included & Included & Included & Included & Included & Included & Included & Included \\
\hline Bank & Included & Included & Included & Included & Included & Included & Included & Included & Included \\
\hline Time (Month-Year) & Included & Included & Included & Included & Included & Included & Included & Included & Included \\
\hline Pseudo R-squared & 0.094 & 0.083 & 0.097 & 0.132 & 0.143 & 0.134 & 0.134 & 0.165 & 0.136 \\
\hline P0 & 0.045 & 0.029 & 0.045 & 0.039 & 0.061 & 0.039 & 0.039 & 0.057 & 0.039 \\
\hline Observations & 25,391 & 4,364 & 25,391 & 25,380 & 4,345 & 25,380 & 25,380 & 4,345 & 25,380 \\
\hline
\end{tabular}




\section{Table 6: Empirical Relation between Loan Risk and Collateral Types}

This table reports results exploring the empirical relation between loan risk (Risk_Premium and Ex_Post_Nonperformance) and collateral types. The omitted category is all unsecured loans. OLS regressions are estimated for Risk_Premium, defined as the loan interest rate at loan origination minus the rate of U.S. Treasury securities with comparable maturity. Marginal effects from Probit regressions are presented for Ex_Post_Nonperformance, a dummy variable that equals one if a loan is $30+$ days overdue any time after origination or if it is downgraded to the default status (i.e., given a rating of 5). In all cases, standard errors are corrected for heteroskedasticity using White standard errors and are reported in parentheses. ***, **, and * indicate significance at the $1 \%, 5 \%$, and $10 \%$, respectively.

\begin{tabular}{|c|c|c|c|c|c|c|c|}
\hline & \multicolumn{4}{|c|}{$\begin{array}{c}\text { Risk_Premium } \\
\text { (OLS) }\end{array}$} & \multicolumn{3}{|c|}{$\begin{array}{c}\text { Ex_Post_Nonperformance } \\
\text { (Probit Model - Marginal Effects) }\end{array}$} \\
\hline & I & II & III & IV & $\mathrm{V}$ & VI & VII \\
\hline \multicolumn{8}{|l|}{ Liquid Collateral Types } \\
\hline Pledged Deposits & $\begin{array}{l}-1.692 * * * \\
(0.123)\end{array}$ & $\begin{array}{l}-1.773 * * * \\
(0.126)\end{array}$ & $\begin{array}{l}-1.168 * * * \\
(0.272)\end{array}$ & $\begin{array}{l}-1.160 * * * \\
(0.289)\end{array}$ & $\begin{array}{c}-0.0233 * * * \\
(0.00772)\end{array}$ & $\begin{array}{l}-0.0175^{*} * \\
(0.00793)\end{array}$ & $\begin{array}{l}-0.0178 * * \\
(0.00776)\end{array}$ \\
\hline Bank Guarantees & $\begin{array}{l}-1.185^{* * *} * \\
\quad(0.221)\end{array}$ & $\begin{array}{l}-0.763 * * * \\
(0.221)\end{array}$ & $\begin{array}{l}-1.142 * * * \\
\quad(0.322)\end{array}$ & $\begin{array}{c}-1.196 * * * \\
(0.342)\end{array}$ & $\begin{array}{c}-0.0227 * * \\
(0.0108)\end{array}$ & $\begin{array}{l}-0.0203 * * \\
(0.00978)\end{array}$ & $\begin{array}{l}-0.0179 * \\
(0.0107)\end{array}$ \\
\hline Securities & $\begin{array}{l}-0.718 * * * \\
(0.183)\end{array}$ & $\begin{array}{l}-0.820 * * * * \\
(0.184)\end{array}$ & $\begin{array}{l}-0.403 \\
(0.486)\end{array}$ & $\begin{array}{l}-0.217 \\
(0.415)\end{array}$ & $\begin{array}{c}0.0156 \\
(0.0247)\end{array}$ & $\begin{array}{l}0.00928 \\
(0.0218)\end{array}$ & $\begin{array}{c}0.0121 \\
(0.0228)\end{array}$ \\
\hline \multicolumn{8}{|l|}{ Illiquid Collateral Types } \\
\hline Creditor-Held Movable Assets & $\begin{array}{l}-0.965 * * * \\
(0.0974)\end{array}$ & $\begin{array}{l}-0.822 * * * \\
(0.0958)\end{array}$ & $\begin{array}{l}-0.823 * * * \\
(0.140)\end{array}$ & $\begin{array}{c}-0.658 * * * \\
(0.139)\end{array}$ & $\begin{array}{c}0.0154 \\
(0.00942)\end{array}$ & $\begin{array}{c}0.00264 \\
(0.00754)\end{array}$ & $\begin{array}{l}0.000867 \\
(0.00731)\end{array}$ \\
\hline Debtor-Held Movable Assets & $\begin{array}{l}-0.820 * * * \\
(0.0892)\end{array}$ & $\begin{array}{l}-0.657 * * * \\
(0.0815)\end{array}$ & $\begin{array}{l}-0.597 * * \\
(0.252)\end{array}$ & $\begin{array}{c}-0.556 * * \\
(0.253)\end{array}$ & $\begin{array}{c}0.0797 * * * \\
(0.0116)\end{array}$ & $\begin{array}{l}0.0619 * * * \\
(0.0104)\end{array}$ & $\begin{array}{l}0.0658 * * * \\
(0.0108)\end{array}$ \\
\hline Residential Real Estate & $\begin{array}{c}0.742 * * * \\
(0.0861)\end{array}$ & $\begin{array}{l}0.558 * * * \\
(0.0842)\end{array}$ & $\begin{array}{l}-0.156 \\
(0.161)\end{array}$ & $\begin{array}{l}0.0927 \\
(0.161)\end{array}$ & $\begin{array}{c}0.0511 * * * \\
(0.0130)\end{array}$ & $\begin{array}{l}0.0499 * * * \\
(0.0127)\end{array}$ & $\begin{array}{c}0.0470^{* * * *} \\
(0.0125)\end{array}$ \\
\hline Commercial Real Estate & $\begin{array}{c}-0.368 * * * \\
(0.120)\end{array}$ & $\begin{array}{c}-0.496^{* * * *} \\
(0.119)\end{array}$ & $\begin{array}{l}-0.406 \\
(0.302)\end{array}$ & $\begin{array}{c}-0.00847 \\
(0.290)\end{array}$ & $\begin{array}{c}0.0733 * * * \\
(0.0184)\end{array}$ & $\begin{array}{c}0.0766 * * * \\
(0.0184)\end{array}$ & $\begin{array}{c}0.0749 * * * \\
(0.0187)\end{array}$ \\
\hline Collateral Bonds & $\begin{array}{c}-0.343 * * * \\
(0.0821)\end{array}$ & $\begin{array}{c}-0.332 * * * \\
(0.0832)\end{array}$ & $\begin{array}{c}-0.382^{* * * *} \\
(0.121)\end{array}$ & $\begin{array}{c}-0.318 * * * \\
(0.113)\end{array}$ & $\begin{array}{c}0.0159 \\
(0.00967)\end{array}$ & $\begin{array}{c}0.00522 \\
(0.00807)\end{array}$ & $\begin{array}{c}0.00751 \\
(0.00842)\end{array}$ \\
\hline Vehicles & $\begin{array}{l}-0.157 \\
(0.157)\end{array}$ & $\begin{array}{l}-0.311 * \\
(0.165)\end{array}$ & $\begin{array}{l}-0.353 \\
(0.312)\end{array}$ & $\begin{array}{l}0.0487 \\
(0.239)\end{array}$ & $\begin{array}{l}0.0583 * \\
(0.0330)\end{array}$ & $\begin{array}{c}0.0708 * * \\
(0.0360)\end{array}$ & $\begin{array}{l}0.0603 * \\
(0.0336)\end{array}$ \\
\hline \multicolumn{8}{|l|}{ Past Nonperformance } \\
\hline Prior Default & & $\begin{array}{c}0.582 * * \\
(0.236)\end{array}$ & & & & $\begin{array}{c}0.0202 \\
(0.0253)\end{array}$ & $\begin{array}{c}0.0180 \\
(0.0245)\end{array}$ \\
\hline Prior NPL & & $\begin{array}{c}0.471 * * * \\
(0.0294)\end{array}$ & & & & $\begin{array}{l}0.0607 * * * \\
(0.00436)\end{array}$ & $\begin{array}{l}0.0617 * * * \\
(0.00440)\end{array}$ \\
\hline \multicolumn{8}{|l|}{ Firm Characteristics } \\
\hline General Partnership & & $\begin{array}{c}-0.431 * * * \\
(0.137)\end{array}$ & & & & $\begin{array}{l}-0.0117 \\
(0.0101)\end{array}$ & $\begin{array}{c}-0.0137 \\
(0.00959)\end{array}$ \\
\hline Limited Partnership & & $\begin{array}{c}-0.319 * * * \\
(0.0477)\end{array}$ & & & & $\begin{array}{l}0.0134 * * \\
(0.00574)\end{array}$ & $\begin{array}{l}0.0144 * * \\
(0.00582)\end{array}$ \\
\hline Joint Stock & & $\begin{array}{c}-1.213 * * * \\
(0.0434)\end{array}$ & & & & $\begin{array}{l}-0.00497 \\
(0.00425)\end{array}$ & $\begin{array}{l}-0.00152 \\
(0.00451)\end{array}$ \\
\hline Limited Liability Company & & $\begin{array}{c}-0.366 * * * \\
(0.0359)\end{array}$ & & & & $\begin{array}{c}0.00776 * * \\
(0.00391)\end{array}$ & $\begin{array}{l}0.00848 * * \\
(0.00390)\end{array}$ \\
\hline \multicolumn{8}{|l|}{ Relation Characteristics } \\
\hline Rel_Length & & $\begin{array}{c}0.0451 * * * \\
(0.0161)\end{array}$ & & & & $\begin{array}{l}-0.00115 \\
(0.00159)\end{array}$ & $\begin{array}{l}-0.000984 \\
(0.00159)\end{array}$ \\
\hline \multicolumn{8}{|l|}{ Other Loan Characteristics } \\
\hline Installment & $\begin{array}{c}0.0242 \\
(0.0266)\end{array}$ & $\begin{array}{l}0.00738 \\
(0.0257)\end{array}$ & $\begin{array}{c}0.0465 \\
(0.0487)\end{array}$ & $\begin{array}{c}0.565 * * * \\
(0.0640)\end{array}$ & $\begin{array}{c}0.0217 * * * \\
(0.00290)\end{array}$ & $\begin{array}{l}0.0197 * * * \\
(0.00268)\end{array}$ & $\begin{array}{l}0.0158 * * * \\
(0.00343)\end{array}$ \\
\hline Maturity & & & & $\begin{array}{c}0.0159 \\
(0.0202) \\
-0.535 * * * \\
(0.0426)\end{array}$ & & & $\begin{array}{c}-0.00389 * * * \\
(0.000894) \\
0.00368 * \\
(0.00203)\end{array}$ \\
\hline Constant & $\begin{array}{l}11.06 * * * \\
(0.0947)\end{array}$ & $\begin{array}{c}10.71 * * * \\
(0.124)\end{array}$ & $\begin{array}{c}9.248 * * * \\
(0.0245) \\
\end{array}$ & $\begin{array}{c}9.864 * * * \\
(0.203)\end{array}$ & & & \\
\hline \multicolumn{8}{|l|}{ Fixed Effects } \\
\hline Industry & & Included & & & & Included & Included \\
\hline Region & Included & Included & & & Included & Included & Included \\
\hline Bank & Included & Included & & & Included & Included & Included \\
\hline Time (Month-Year) & Included & Included & & & Included & Included & Included \\
\hline Firm*Bank*Time & & & Included & Included & & & \\
\hline (Adjusted) R-Square & 0.363 & 0.414 & 0.922 & 0.925 & & & \\
\hline Pseudo R-Square & & & & & 0.100 & 0.138 & 0.140 \\
\hline PO & & & & & 0.044 & 0.039 & 0.039 \\
\hline Observations & 28,252 & 28,252 & 13,274 & 13,274 & 25,391 & 25,380 & 25,380 \\
\hline
\end{tabular}

